\title{
Arbuscular mycorrhizal fungi in a semi-arid, limestone mining-impacted area of Brazil
}

Thaís Teixeira-Rios ${ }^{1}$, Renata Gomes de Souza ${ }^{1}$, Leonor Costa Maia ${ }^{1}$, Fritz Oehl ${ }^{2}$ and Cláudia Elizabete Pereira Lima ${ }^{1,3}$

Received: 9 February, 2013. Accepted: 7 July, 2013

\begin{abstract}
The main goal of this study was to determine the diversity and activity of arbuscular mycorrhizal fungi (AMF) in an area degraded by limestone mining within the semi-arid region of Brazil known as the caatinga (shrublands). Near a limestone quarry, we selected two areas of caatinga (preserved and degraded) for study. The number of glomerospores did not differ significantly between the two areas. There was a trend toward the most probable number of infective propagules being higher in the degraded area. Twenty AMF taxa were identified in the two sampled areas, species richness, diversity and evenness being higher in the preserved area. Two species of Racocetra represent new records for the semi-arid region of Brazil. Glomerospore production and AMF species richness were unaffected by mining activity in the study area.
\end{abstract}

Key words: caatinga, glomerospores, infective propagules, mining activities, mycorrhiza

\section{Introduction}

Many interactions take place among the physical, chemical and biological components of soil, whose functionality depends on the environment in which it is located (Nannipieri et al. 2003). Particularly in the rhizosphere, various microbiological communities are essential for the occurrence of fundamental processes, such as biochemical cycling of the nutrients that influence the formation and maintenance of the soil and consequently the sustainability of land ecosystems (Barea et al. 2005).

The majority of plants form mycorrhizae, symbiotic associations with fungi that live in the root system. Those associations exercise an essential function for the structure and stability of plant communities. Arbuscular mycorrhizal fungi (AMF) are associated with representatives of more than $90 \%$ of the vascular plant families and, as obligate symbionts, are nutritionally dependent on the host plant (Smith \& Read 2008). In exchange for plant-derived carbon, AMF facilitate plant absorption and uptake of nutrients from the soil, such as phosphorus (Jakobsen et al. 2001), and can increase plants' tolerance to toxic elements (Cumming \& Ning 2003; Gattai et al. 2011), plant pathogens (Declerck et al. 2002), saline stress (Yano-Melo et al. 2003) and erosion (O'Dea 2007). The AMF can also help stabilize and aggregate soil, increasing the levels of soluble carbon and enzymes (e.g., urease, acid phosphatase and $\beta$-glucosidase), making them an important component to improve the growth of young plants under severe climate conditions (Caravaca et al. 2002).

Mining activity occurs in $26 \%$ of the municipalities within the semi-arid region of Brazil (DNPM 2009) and constitutes one of the human activities that most alters the land surface in the region. This activity can cause serious problems related to soil structure, water availability, biological activity, as well as to the supply of sulfur, phosphorus and nitrogen to plants, resulting in reduced productivity (Ferreira et al. 2007).

In arid and semi-arid regions, the generally low soil fertility makes plants highly dependent on mycorrhization (Tarafdar \& Praveen-Kumar 1996), and it is therefore important to quantify the diversity of AMF in these regions, mainly in areas subject to degradation, such as those affected by mining activities. Due to the relevant role these fungi play in ecosystems, in this study we investigated the diversity, number of glomerospores and potential infectivity of AMF in an area of the Brazilian caatinga (shrublands) degraded by limestone mining, comparing the results with those obtained for a nearby preserved area.

\footnotetext{
${ }^{1}$ Universidade Federal de Pernambuco, Centro de Ciências Biológicas, Departamento de Micologia, Recife, PE, Brazil

${ }^{2}$ Federal Research Institute Agroscope Reckenholz-Tänikon ART, Organic Farming Systems, Zürich, Switzerland

${ }^{3}$ Author for correspondence: claudiaeplima@gmail.com
} 


\section{Material and methods}

\section{Study areas}

The investigated areas are located on a property owned by the company Cimpor Cimentos Brazil, in the municipality of Campo Formoso (10 $30^{\prime} 27^{\prime \prime S}$; $\left.40^{\circ} 19^{\prime} 17^{\prime \prime} \mathrm{W}\right)$, located within the São Francisco River Valley, which is in the northern part of the state of Bahia, Brazil. The climate is semi-arid, with irregular rainfall, ranging from 300 to 700 $\mathrm{mm}$ /year, most of the rainfall occurring between November and March. The average annual temperature is $22-23^{\circ} \mathrm{C}$, and the average relative air humidity is $20 \%$, making the region highly arid. The terrain is mostly flat, covered by spiny deciduous shrubs and bushes (typical of the caatinga), forming a generally open landscape, interspersed with a few emergent trees and virtually no herbaceous layer in the dry season (PRAD Cimpor 2004).

\section{Data collection}

Soil samples were collected in October 2008 (dry season), during which the average monthly temperature was $23.8^{\circ} \mathrm{C}$ and evapotranspiration was $36.4 \mathrm{~mm}$. We selected two areas of caatinga vegetation for study: a preserved area; and an area degraded by limestone mining. In each area, an imaginary zig-zag line was traced and 20 soil samples (each comprising three subsamples of ca. $0.5 \mathrm{~kg}$ ) were collected and placed in plastic bags for AMF studies. A single composite soil sample (ca. $1.0 \mathrm{~kg}$ ) for each area was taken to the Soil Laboratory of the Pernambuco Institute of Agronomy for physical and chemical analyses (Tab. 1).

\section{Evaluation of mycorrhizae}

Glomerospores were extracted from $100 \mathrm{~g}$ of 20 soil samples by wet sieving (Gerdemann \& Nicolson 1963), followed by centrifuging in water and sucrose at $50.0 \%$ (modified from Jenkins 1964). The glomerospores were then quantified in Petri dishes with a stereomicroscope (40×).

The most probable number (MPN) of infective propagules in the soil was evaluated according to Feldmann \& Idzack (1994). For each area, we prepared a compound sample, which was diluted in washed, autoclaved sand at four dilution levels (no dilution; 1/10; 1/100; and 1/1000), with five replicates. Two corn seeds (Zea mays L.) were planted in each pot $(150 \mathrm{ml})$. At 10 days after sowing, the seedlings were culled, leaving only one plant per pot. The plants were harvested at 30 days after culling. The roots were washed in running water, stained according to Phillips \& Haymann (1970) and evaluated for the presence of mycorrhizal colonization.

We used the soil samples in order to quantify the glomerospores and to identify the AMF species directly or after growth in trap cultures using sorghum (Sorghum bicolor (L.)
Moench) and peanut (Arachis hypogaea L.) as host plants. The trap cultures were kept in a greenhouse for three months and watered every other day. Glomerospores were extracted as described above, mounted on slides with polyvinyl-lactoglycerol (PVLG) or with Melzer's reagent + PVLG (1:1 v/v) and observed under microscopy. For species identification, we consulted Schenck \& Pérez (1990) and the International Culture Collection of (Vesicular) Arbuscular Mycorrhizal Fungi (http://invam.caf.wvu.edu), as well as new descriptions. The classification follows Oehl et al. (2011).

\section{Data analysis}

The numbers of glomerospores were analyzed by oneway ANOVA using the two areas (preserved and degraded) as variables. Means were compared by the Tukey's test $(p<0.05)$.

The Shannon diversity index $\left(H^{\prime}\right)$ was calculated according to the following equation:

$$
H^{\prime}=-\sum(P i \ln [P i])
$$

where $P i$ is the relative abundance (the number of individuals of the species $i$ in relation to the total number of individuals of all species), and $\ln$ is the natural log. Pielou's evenness index $\left(J^{\prime}\right)$ was obtained by the following equation:

$$
J^{\prime}=H^{\prime} / \log (S)
$$

where $S$ is the total number of species obtained with the PAleontological STatistics (PAST) program (Hammer et al. 2001). The species accumulation curve and the first-order Jackknife (Jackknife 1) index were estimated using the Primer 6.0 program (Clarke \& Gorley 2006). The similarity between the two areas was estimated by the Sørensen index (Brower \& Zar 1984). In accordance with Zhang et al. (2004), we defined the following categories of frequency of occurrence: dominant (> 50.0\%); quite common (31.0-50.0\%); common (10.0-30.0\%); and rare $(<10.0 \%)$.

\section{Results and discussion}

The number of glomerospores did not differ significantly between the preserved and degraded areas (164.0 \pm $44.0 / 100 \mathrm{~g} \mathrm{~g}^{-1}$ soil vs. $186.0 \pm 47.0 / 100 \mathrm{~g}^{-1}$ soil). In both areas, the number of glomerospores was relatively low, as is common in arid and semi-arid regions (Requena et al. 1996). The high $\mathrm{pH}$ and limited availability of nutrients in the soil (Tab. 1), especially P, may have contributed to the small number of glomerospores (Entry et al. 2002). In an earlier study, Silva et al. (2001) obtained a similar result for an area of caatinga degraded by copper mining, reporting $<160.0$ glomerospores $/ 100 \mathrm{~g}^{-1}$ soil, suggesting that this response is related to host plant or soil toxicity in the area. However, in areas replanted after bauxite mining, Caproni et al. (2005) found an average of 2335.0 glomerospores $/ 100 \mathrm{ml}^{-1}$ soil, which can be considered a high density. More recently, La- 
Table 1. Physico-chemical characteristics of the soil samples collected in preserved and degraded areas of caatinga (shrublands) in the municipality of Campo Formoso, in the state of Bahia, Brazil.

\begin{tabular}{ccccccccccc}
\hline \multirow{2}{*}{ Area } & $\mathrm{pH}$ & $\mathrm{P}$ & $\mathrm{Ca}$ & $\mathrm{Mg}$ & $\mathrm{Na}$ & $\mathrm{K}$ & $\mathrm{Al}$ & Sand & Silt & Clay \\
\cline { 2 - 10 } & $\mathrm{H}_{2} \mathrm{O}$ & $\mathrm{mg} / \mathrm{dm}^{-3}$ & $\mathrm{mg} / \mathrm{dm}^{-3}$ & $\mathrm{mg} / \mathrm{dm}^{-3}$ & $\mathrm{mg} / \mathrm{dm}^{-3}$ & $\mathrm{mg} / \mathrm{dm}^{-3}$ & $\mathrm{mg} / \mathrm{dm}^{-3}$ & $\%$ & $\%$ & $\%$ \\
Preserved & 7.3 & 42 & 11.00 & 1.55 & 0.07 & 1.2 & 0.0 & 35 & 33 & 32 \\
Degraded & 7.8 & 18 & 11.25 & 1.95 & 0.13 & 0.8 & 0.0 & 32 & 43 & 25 \\
\hline
\end{tabular}

bidi et al. (2011) reported that $\mathrm{CaCO}_{3}$ has harmful effects on the colonization and number of mycorrhizal structures (arbuscules, vesicles, external mycelia and glomerospores) of Glomus irregulare Blaszk., Wubet, Renker \& Buscot, with a negative impact on the fungus life cycle during the pre-symbiotic (germination) and symbiotic phases in the root systems of transformed chicory (Cichorium intybus L.). In the present study, the limestone quarry did not appear to have a negative influence on the formation of glomerospores, given that similar number was found in both areas.

We observed a trend toward the number of infective propagules being higher in the degraded area than in the preserved area $\left(35.0 / \mathrm{cm}^{-3}\right.$ soil vs. $13.0 / \mathrm{cm}^{-3}$ soil). The distribution and abundance of AMF propagules can also be related to the complexity of the mycorrhizal community (Ramos-Zapata et al. 2011). The number of infective propagules, together with the low number of glomerospores, can indicate that the infectivity of the AMF in the sampled areas is more dependent on colonized roots than on glomerospores, and the stressful conditions in the area surrounding the mine possibly induces lower infectivity, corroborating the results of other studies conducted in the caatinga (Lima et al. 2007; Mergulhão et al. 2007). A similar result was found in a mined area covered with molasses grass, guandu beans (pigeon peas) and native plants, where the authors observed 39.3 propagules $/ \mathrm{g}^{-1}$ soil, while in a closed forest area containing tree species the number was only 11.2 propagules $/ \mathrm{g}^{-1}$ soil (Melloni et al. 2003). In another area of caatinga in the state of Bahia, Silva et al. (2001) found a much lower number of propagules $\left(0.15 / \mathrm{cm}^{-3}\right.$ soil). Although the methods used by Melloni et al. (2003) and Silva et al. (2001) to evaluate the MPN of propagules were different from that used in the present study, the fact that the MPN of infective propagules identified here was nearly 90 times higher than that reported by Silva et al. (2001) suggests a significant difference between the two studies, underscoring the need for standardization of methods in mycorrhizal studies (Maia et al. 2010).

In the present study, we found no difference between the preserved and degraded areas in terms of AMF diversity, evenness or richness, as measured by the Shannon index $\left(\mathrm{H}^{\prime}\right.$ $=2.30$ and $\mathrm{H}^{\prime}=2.12$, respectively), Pielou's index $\left(\mathrm{J}^{\prime}=0.81\right.$ and $\mathrm{J}^{\prime}=0.78$, respectively) and the total number of species (17 and 15, respectively). Regarding AMF diversity, 12 species occurred in both areas, representing a 75.0\% similarity, which can be related to the nonspecific nature of the AMF, independent of the local conditions (Dandan \& Zhiwei 2007). In a study conducted in India, Radhika $\&$ Rodrigues (2010) compared AMF diversity between two areas with different levels of available P. The authors found that other physico-chemical conditions of the soil, such as texture and $\mathrm{pH}$, also influenced AMF diversity and dominance. Although AMF are commonly found in arid regions, their diversity declines as aridity increases (Stutz \& Morton 1996). In another study conducted in the caatinga of northeastern Brazil, Maia et al. (2010) identified over 70 species of AMF. In the Xingó region, located in the state of Alagoas, Souza et al. (2003) identified 24 AMF taxa, some of which were also found in this study: Acaulospora longula, Claroideoglomus etunicatum, Funneliformis mosseae and Paraglomus occultum. In the municipality of Jaguarari, in the state of Bahia, Silva et al. (2005) identified 15 AMF species, six of which were also registered in our study: Entrophospora infrequens, C. etunicatum, Glomus macrocarpum, G. microcarpum, F. mosseae and P. occultum.

In the present study, we identified a total of $20 \mathrm{AMF}$ taxa (Tab. 2). We observed more AMF species in the preserved area than in the degraded area, with an overall dominance of Glomus macrocarpum, followed by Claroideoglomus etunicatum, which was dominant in the degraded area and quite common in the preserved area. The other species were classified as common or rare in both areas. The sampling effort was sufficiently efficient to recover $83.0 \%$ of the total species, as determined by the Jackknife 1 estimator (Figure 1). Species observed in the trap cultures did not differ from those found in the field.

The predominance of representatives of Glomeraceae (Glomus and Funneliformis) and Entrophosporaceae (Claroideoglomus and Entrophospora) confirms the tolerance of these individuals to soil disturbances and anthropogenic environments and acid to neutral soils (Boddington \& Dodd 2000; Sieverding \& Oehl 2006). Species of the genus Acaulospora have often been associated with acidic soils (Morton 1986; Abbott \& Robson 1991). However, in the present study, various species of that genus were found to occur on alkaline soil, also a frequent finding in arid areas of tropical zones (Tao \& Zhiwei 2005), although less so in subtropical zones and rarely in colder climates (Yang et al. 2011). Representatives of the Glomus genus are also commonly found in arid regions (Pande \& Tarafdar 2004; Silva et al. 2005; Tian et al. 2009; Mello et al. 2012), where their occurrence is related to variations in the edaphic conditions, 
Table 2. Arbuscular mycorrhizal fungi in preserved and degraded areas of caatinga (shrublands) in the municipality of Campo Formoso, in the state of Bahia, Brazil.

\begin{tabular}{|c|c|c|c|c|}
\hline \multirow{3}{*}{ AMF species } & \multicolumn{2}{|c|}{ Preserved area } & \multicolumn{2}{|c|}{ Degraded area } \\
\hline & \multirow{2}{*}{ NS } & $\mathrm{F}$ & \multirow{2}{*}{ NS } & $\mathrm{F}$ \\
\hline & & $(\%)$ & & (\%) \\
\hline Acaulospora lacunosa J.B. Morton & 0 & 0 & 1 & 5 \\
\hline Acaulospora longula Spain \& N.C. Schenck & 1 & 5 & 1 & 5 \\
\hline Acaulospora mellea Spain \& N.C. Schenck & 1 & 5 & 4 & 20 \\
\hline Acaulospora morrowiae Spain \& N.C. Schenck & 1 & 5 & 0 & 0 \\
\hline Acaulospora scrobiculata Trappe & 0 & 0 & 1 & 5 \\
\hline Ambispora sp. & 2 & 10 & 1 & 5 \\
\hline Claroideoglomus etunicatum (W.N. Becker \& Gerd.) C. Walker \& A. Schuessler & 10 & 50 & 13 & 60 \\
\hline Entrophospora sp. & 10 & 50 & 2 & 10 \\
\hline Entrophospora infrequens (I.R. Hall) R.N. Ames \& R.W. Schneid. & 2 & 10 & 6 & 30 \\
\hline Funneliformis mosseae (T.H. Nicolson \& Gerd.) C. Walker \& A. Schuessler & 6 & 30 & 4 & 20 \\
\hline Glomus sp. 1 & 2 & 10 & 0 & 0 \\
\hline Glomus sp. 2 & 1 & 5 & 1 & 5 \\
\hline Glomus sp. 3 & 1 & 5 & 2 & 10 \\
\hline Glomus brohultii Sieverd. & 0 & 0 & 1 & 5 \\
\hline Glomus macrocarpum Tul. \& C. Tul. & 16 & 75 & 21 & 80 \\
\hline Glomus microcarpum Tul. \& C. Tul. & 1 & 5 & 0 & 0 \\
\hline Pacispora boliviana Sieverd. \& Oehl & 1 & 5 & 4 & 20 \\
\hline Paraglomus occultum (C. Walker) J.B. Morton \& D. Redecker & 5 & 25 & 1 & 5 \\
\hline Racocetra fulgida (Koske \& C. Walker) Oehl, F.A. Souza \& Sieverd. & 1 & 5 & 0 & 0 \\
\hline Racocetra verrucosa (Koske \& C. Walker) Oehl, F.A. Souza \& Sieverd. & 1 & 5 & 0 & 0 \\
\hline Total number of species & 17 & & 15 & \\
\hline Total number of spores & 62 & & 63 & \\
\hline
\end{tabular}

AMF - arbuscular mycorrhizal fungi; NS - number of spores; F - frequency of occurrence of species.

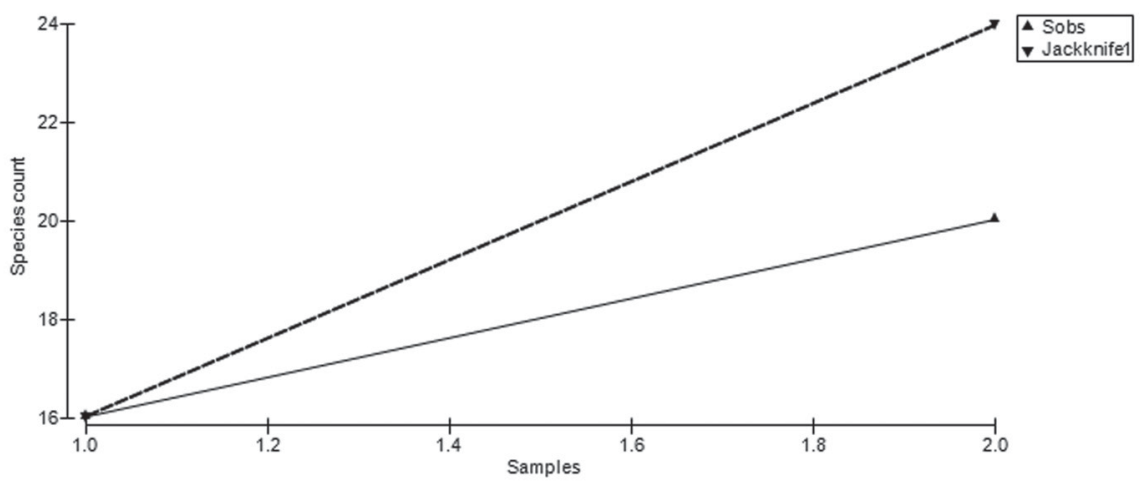

Figure 1. Species accumulation curve, based on the numbers of species observed (Sobs), and the species richness index, determined by the Jackknife first-order (Jackknife 1) estimator, in preserved and degraded areas of caatinga (shrublands) vegetation in the municipality of Campo Formoso, in the state of Bahia, Brazil.

as well as to their high adaptability to varying conditions of soil and temperature, enabling them to survive in acidic and alkaline soils alike. In addition, the great quantity and small size of their glomerospores facilitate distribution in arid environments (Stutz et al. 2000).
Representatives of Ambispora and Entrophospora occurred in both of the areas evaluated in the present study, as did Acaulospora longula, Acaulospora mellea, Claroideoglomus etunicatum, Entrophospora infrequens, Funneliformis mosseae, Glomus macrocarpum, Pacispora 
boliviana and Paraglomus occultum. However, some species (Acaulospora morrowiae, Glomus microcarpum, Racocetra fulgida and $R$. verrucosa) were exclusive to the preserved area, whereas others (Acaulospora lacunosa, Acaulospora scrobiculata and Glomus brohultii) were exclusive to the degraded area.

The application of limestone to the soil did not alter the community of native AMF in degraded areas of the Brazilian savanna (Martins et al. 1999). However, soil disturbances have a large impact on the AMF community (Schnoor et al.2011), possibly reducing the richness of sensitive species and increasing that of tolerant species. In a area of transition between open-pit copper mining and a preserved area of caatinga, Silva et al. (2005) registered Acaulospora scrobiculata, Claroideoglomus etunicatum, Glomus macrocarpum, Funneliformis mosseae and Paraglomus occultum, species also observed in this study (degraded area). Melloni et al. (2003) identified six AMF species in reclaimed areas after bauxite mining, among them A. scrobiculata and P. occultum, species that can be classified as generalists (Oehl et al. 2010; Tchabi et al. 2009), at least in tropical zones.

Information on the diversity of AMF can be used to investigate the function of these fungi in maintaining plant biodiversity and the function of the ecosystem during conservation and restoration of various natural ecosystems, especially in semi-arid zones (Dandan \& Zhiwei 2007). The knowledge of the diversity and activity of AMF obtained here adds to that provided by previous studies conducted in arid areas and areas degraded by mining. New species of AMF have recently been described in the caatinga biome (Goto et al. 2010) and could be exclusive to Brazil. In the present study, the two species of Racocetra are among the first reported for the semi-arid region of Brazil. Our results indicate that the production of glomerospores is not altered by limestone mining activity. Our findings also confirm the predominance of Glomus in areas with a semi-arid climate, as well as showing that species that are more tolerant can be dominant in stressful environments, in contrast to rare species in unaltered environments. Knowledge of AMF diversity in Brazil can inform decisions related to public policies for environmental preservation and programs to produce seedlings of native plants for reclamation of degraded areas in the semi-arid region of the country.

\section{Acknowledgments}

This work was supported by the Brazilian Conselho Nacional de Desenvolvimento Científico e Tecnológico (CNPq, National Council for Scientific and Technological Development; Grant nos. 563342/2010-2 and 562330/2010-0), the Brazilian Coordenação de Aperfeiçoamento de Pessoal de Nivel Superior (CAPES, Office for the Advancement of Higher Education) and the Cimpor Cimentos Company, which provided access for the collection of specimens.

\section{References}

Abbott, L.K. \& Robson, A.D. 1991. Factors influencing the occurrence of vesicular-arbuscular mycorrhizas. Agriculture Ecosystems Environment 35: 121-150.

Barea, J.M.; Pozo, M.J.; Azcón, R. \& Azcón-Aguilar, C. 2005. Microbial cooperation in the rhizosphere. Journal of Experimental Botany 56: $1761-1778$.

Boddington, C.L. \& Dodd, J.C. 2000. The effect of agricultural practices on the development of indigenous arbuscular mycorrhizal fungi. Field studies in an Indonesian ultisol. Plant and Soil 218: 137-144.

Brower, J.E. \& Zar, J.H. 1984. Community similarity. In: Brower JE, Zar $\mathrm{JH}$ (Eds.). Field and laboratory methods for general ecology. 3rd ed. Dubuque, W.C. Brown Publishers.

Caproni, A.L.; Franco, A.A.; Berbara, R.L.L.; Granha, J.R.D.O. \& Marinho, N.F. 2005. Fungos micorrízicos arbusculares em estéril revegetado com Acacia mangium após mineração de bauxita. Revista Árvore 29(3): 373-381.

Caravaca, F.; Hernández, T.; García, C. \& Roldán, A. 2002. Improvement of rhizosphere aggregate stability of afforested semiarid plant species subjected to mycorrhizal inoculation and compost addition. Geoderma 108(1-2): 133-144.

Clarke, K.R. \& Gorley, R.N. 2006. PRIMER v6. In: User Manual/Tutorial. Plymouth, PRIMER-E.

Cumming, J.R. \& Ning, J. 2003. Arbuscular mycorrhizal fungi enhance aluminium resistance of broomsedge (Andropogon virginicus L.). Journal of Experimental Botany 54: (386) 1447-1459.

Dandan, Z. \& Zhiwei, Z. 2007. Biodiversity of arbuscular mycorrhizal fungi in the hot-dry valley of the Jinsha River, southwest China. Applied Soil Ecology 37: 118-128.

Declerck, S.; Risede, J.M.; Rufyikiri, G. \& Delvaux, B. 2002. Effects of arbuscular mycorrhizal fungi on severity of root rot of bananas caused by Cylindrocladium spathiphylli. Plant Pathology 51(1): 109-115.

DNPM, 2009. Mineração no semiárido brasileiro. Brasília, Ministério de Minas e Energia.

Entry, J.A.; Rygiewiczb, P.T.; Watrudb, L.S. \& Donnelly, P.K. 2002. Influence of adverse soil conditions on the formation and function of Arbuscular mycorrhizas. Advances in Environmental Research 7: 123-138.

Feldmann, F. \& Idzack, E. 1994. Inoculum production of vesicular-arbuscular mycorrhizal fungi for use in tropical nurseries. Pp.799- 817. In: Norris JR, Read DJ, Varma AK (Eds.). Techniques for mycorrhizal research. San Diego, Academic Press.

Ferreira, A.P.; Campello, E.F.C.; Franco, A.A. \& Resende, A.S. 2007. Uso de leguminosas arbóreas fixadoras de nitrogênio na recuperação de áreas degradadas pela mineração de areia no polo produtor de Seropédica/Itaguaí. Seropédica, Embrapa Agrobiologia. 31 p. (Documentos/ Embrapa Agrobiologia)

Gattai, G.S.; Pereira, S.V.; Costa, C.M.C.; Lima, C.E.P. \& Maia, L.C. 2011. Microbial activity arbuscular mycorrhizal fungi and inoculation of woody plants in lead contaminated soil. Brazilian Journal of Microbiology 42: 859-867

Gerdemann, J.W. \& Nicolson, T.H. 1963. Spores of mycorrhizal Endogone species extracted from soil by wet sieving and decanting. Transactions of the British Mycological Society 46: 235-244.

Goto, B.T.; Silva, G.A.; Yano-Melo, A.M. \& Maia, L.C. 2010. Checklist of the arbuscular mycorrhizal fungi (Glomeromycota) in the Brazilian semiarid. Mycotaxon 113: 251-254.

Hammer, O.; Harper, D.A.T. \& Rian, P.D. 2001. Past: Palaeonthological statistics software package for education and data analysis. Version. 1.37. Disponível em: <http://palaeo-electronica.org/2001_1/past/ issue1_01.htm>. (Acesso em 13.05.2013).

Jakobsen, I.; Gazey, C. \& Abbott, L.K. 2001. Phosphate transport by communities of arbuscular mycorrhizal fungi in intact soil cores. New Phytologist 149: 95-103.

Jenkins, W.R. 1964. A rapid centrifugal-flotation technique for separating nematodes from soil. Plant Disease Report 48: 692.

Labidi, S.; Calonne, M.; Jeddi, F.B.; Debiane, D.; Rezgui, S.; Laruelle, F.; Tisserant, B.; Grandmougin-Ferjani, A. \& Sahraoui, A.L.H. 2011. Calcareous impact on arbuscular mycorrhizal fungus development and on lipid peroxidation in monoxenic roots. Phytochemistry 72: 2335-2341. 
Lima, R.L.F.A.; Salcedo, I.H. \& Fraga, V.S. 2007. Propágulos de fungos micorrízicos arbusculares em solos deficientes em fósforo sob diferentes usos da região semi-árida no nordeste do Brasil. Revista Brasileira de Ciência do Solo 31: 257-268.

Maia, L.C.; Silva, G.A.; Yano-Melo, A.M. \& Goto, B.T. 2010. Fungos micorrízicos arbusculares no Bioma Caatinga. In: Siqueira, J.O.; Souza, F.A.; Cardoso, J.B.N. \& Tsai, S.M. (Eds.). Micorrizas 30 anos de pesquisas no Brasil. Lavras, Editora UFLA.

Martins, C.R.; Miranda, J.C.C. \& Miranda, L.N. 1999. Contribuição de fungos micorrízicos arbusculares nativos no estabelecimento de Aristida setifolia Kunth em áreas degradadas do cerrado. Pesquisa Agropecuária Brasileira 34(4): 665-674.

Mello, C.M.A.; Silva, I.R.; Pontes, J.S.; Goto, B.T.; Silva, G. A.; Maia, L.C. 2012. Diversidade de fungos micorrízicos arbusculares em área de Caatinga, PE, Brasil. Acta Botanica Brasilica 26(4): 938-943.

Melloni, R.; Siqueira, J.O. \& Moreira, F.M.S. 2003. Fungos micorrízicos arbusculares em solos de área de mineração de bauxita em reabilitação. Pesquisa Agropecuária Brasileira 38(2): 267-276.

Mergulhão, A.C.E.S.; Oliveira, J.P.; Burity, H.A. \& Maia, L.C. 2007. Potencial de infectividade de fungos micorrízicos arbusculares em áreas nativas e impactadas por mineração gesseira no semi-árido brasileiro. Hoehnea 34(3): 341-348.

Morton, J.B. 1986. Three new species of Acaulospora (Endogonaceae) from high-aluminium low pH soils in West Virginia. Mycologia 78: 641-648.

Nannipieri, P.; Ascher, J.; Ceccherini, M.T.; Landi, L. \& Pietramellara. G. 2003. Microbial diversity and soil functions. European Journal of Soil Science 54: 655-670.

O'dea, M.E. 2007. Fungal mitigation of soil erosion following burning in a semi-arid Arizona savanna. Geoderma 138(1-2): 79-85.

Oehl, F.; Laczko, E.; Bogenrieder, A.; Stahr, K.; Bösch, R.; Van Der Heijden, M. \& Sieverding, E. 2010. Soil type and land use intensity determine the composition of arbuscular mycorrhizal fungal communities. Soil Biology and Biochemistry 42: 724-738.

Oehl. F.; Sieverding, E.; Palenzuela, J.; Ineichen, K. \& Silva, G.A. 2011. Advances in Glomeromycota taxonomy and classification. IMA Fungus 2: 191-199.

Pande, M. \& Tarafdar, J.C. 2004. Arbuscular mycorrhizal fungal diversity in neem-based agroforestry systems in Rajasthan. Applied Soil Ecology 26: 233-241.

Phillips, J.M. \& Hayman, D.S. 1970. Improved procedures for cleaning roots and staining parasitic and vesicular-arbuscular mycorrhizal fungi for rapid assessment of infection. Transactions of the British Mycological Society 55: 158-161.

PRAD CIMPOR, 2004. Plano de Recuperação de Área Degradada. Elaborado por Osmar Martins dos Santos.

Radhika, K.P. \& Rodrigues, B.F. 2010. Arbuscular mycorrhizal fungal diversity in some commonly occurring medicinal plants of Western Ghats, Goa region. Journal of Forestry Research 21(1): 45-52.

Ramos-Zapata, J.A.; Zapata-Trujillo, R.; Ortiz-Diaz, J.J. \& Guadarrama, P. 2011. Arbuscular mycorrhizas in a tropical coastal dune system in Yucatan Mexico. Fungal Ecology 4: 256-261.

Requena, N.; Jeffries, P. \& Barera, J.M. 1996. Assessment of natural mycorrhizal potential in a desertified semiarid ecosystem. Applied and Environmental Microbiology 62: 842-847.
Schenck, N.C. \& Pérez, Y. 1990. Manual for the identification of VA mycorrhizal fungi. 3rd ed. Synergistic Publ. Gainesville.

Schnoor, T.K.; Lekberg, Y.; Rosendahl, S. \& Olsson, P.A. 2011. Mechanical soil disturbance as a determinant of arbuscular mycorrhizal fungal communities in semi-natural grassland. Mycorrhiza 21: 211-220.

Sieverding, E. \& Oehl, F. 2006. Revision of Entrophospora and description of Kuklospora and Intraspora, two new genera in the arbuscular mycorrhizal Glomeromycetes. Journal of Applied Botany and Food Quality 80: 69-81.

Silva, G.A.; Maia, L.C.; Silva, F.S.B. \& Lima, P.C.F. 2001. Potencial de infectividade de fungos micorrízicos arbusculares oriundos de área de caatinga nativa e degradada por mineração no Estado da Bahia Brasil. Revista Brasileira de Botânica 24(2): 135-143.

Silva, G.A.; Silva, F.S.B.; Trufem, S.F.B.; Saggin Junior, O.J. \& Maia, L.C. 2005. Arbuscular mycorrhizal fungi in a semiarid copper mining area in Brazil. Mycorrhiza 15: 47-53.

Smith, S.E. \& Read, D.J. 2008. The symbiont forming arbuscular mycorrhizas. Pp. 13-41. In: Smith, S.E. \& Read, D.J. (Eds.). Mycorrhizal Symbiosis. 2. ed. San Diego, Academic Press.

Souza, R.G.; Maia, L.C.; Sales, M.F.; Trufem, S.F.B. 2003. Diversidade e potencial de infectividade de fungos micorrízicos arbusculares em área de caatinga na Região de Xingó Estado de Alagoas Brasil. Revista Brasileira de Botânica 26: 49-60.

Stutz, J. \& Morton, J.B. 1996. Successive pot cultures reveal high species richness of indigenous arbuscular endomycorrhizal fungi in arid ecosystems. Canadian Journal of Botany 74: 1883-1889.

Stutz, J.C.; Copeman, R.; Martin, C.A. \& Morton, J.B. 2000. Patterns of species composition and distribution of arbuscular mycorrhizal fungi in arid regions of southwestern North America and Namibia Africa. Canadian Journal of Botany 78: 237-245.

Tao, L. \& Zhiwei, Z. 2005. Arbuscular mycorrhizas in a hot and arid ecosystem in southwest China. Applied Soil Ecology 29: 135-141.

Tarafdar, J.C. \& Praveen-Kumar, J.C. 1996. The role of vesicular arbuscular mycorrhizal fungi on crop tree and grasses grown in an arid environment. Journal of Arid Environments 34: 197-203.

Tchabi, A.; Burger, S.; Coyne, D.; Hountondji, E.; Lawouin, L.; Wiemken, A. \& Oehl, F. 2009. Promiscuous arbuscular mycorrhizal symbiosis of yam (Dioscorea spp.), a key staple crop in West Africa. Mycorrhiza 19: $375-392$

Tian, H.; Gai, J.P.; Zhang, J.L.; Christie, P. \& Li, X.L. 2009. Arbuscular mycorrhizal fungi associated with wild forage plants in typical steppe of eastern Inner Mongolia. European Journal of Soil Biology 45: 321-327.

Yang, A.; Lu, L. \& Zhang, N. 2011. The diversity of arbuscular mycorrhizal fungi in the subtropical forest of Huangshan (Yellow Mountain), EastCentral China. World Journal of Microbiology and Biotechnology 27(10): 2351-2358.

Yano-Melo, A.M.; Saggin Jr., O.J. \& Maia, L.C. 2003. Tolerance of mycorrhized banana (Musa sp. cv. Pacovan) plantlets to saline stress. Agriculture, Ecosystems and Environment 95: 343-348.

Zhang, Y.; Gui, L.D.; Liu, R.J. 2004. Survey of arbuscular mycorrhizal fungi in deforested and natural forest land in the subtropical region of Dujiangyan, southwest China. Plant Soil 261: 257-263. 